\title{
Optimizing plant density and balancing NPK inputs in combination with innovative fertilizer product for sustainable maize production in North China Plain.
}

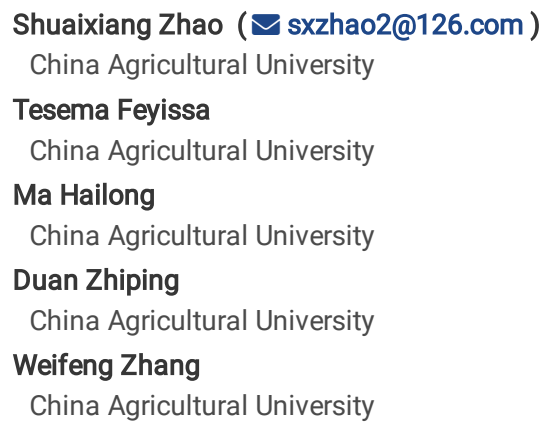




\section{Abstract}

Excessive NPK inputs but low grain yield and high environmental impact are common in maize production in North China Plain (NCP). The objective of our study was to test whether a combined strategy of optimizing plant density, balancing NPK input, and innovating one-time fertilizer products could achieve a more sustainable maize production in NCP. Thus, a field experiment was conducted at Luanna County NCP with the treatments of unfertilized control (CK), farmer practice (FP, conventional plant density and NPK input), conventional one-time urea-based coated fertilizer (CF, optimized plant density and NPK input), and five newly designed innovative one-time NPK fertilizers of ammonium sulphate and urea synergy (IF, optimized plant density and NPK input), innovative fertilizer with various additives of urea inhibitors (IF+UI), double inhibitors (IF+DI), micro-organisms (IF+MI), and trace elements (IF+TE). The grain yield, nitrogen sustainability indicators (nitrogen use efficiency NUE, partial factor productivity of nitrogen PFPN, and nitrogen surplus), and cost-benefits analysis were measured and calculated over the maize growing season of 2020. Results had shown that on average the five innovative fertilizers (IF, IF+UI, IF+DI, IF+MI, and IF+TE) and CF that had optimized plant density and NPK input achieved $13.5 \%, 98.6 \%, 105.9 \%, 37.4 \%$ higher yield, PFPN, NUE, net-benefits as well as $67.5 \%$ lower $\mathrm{N}$ surplus compared with FP respectively. Notably, the innovative fertilizer with various effective additives (IF+UI, IF+DI, IF+MI, and IF+TE) which can be commonly found in the fertilizer market hadn't resulted in an improvement in yield and NUE rather a greater cost and small net benefits in comparison to IF. In summary, our study highlighted the effectiveness of the combined strategy of optimized plant density, balancing NPK input, and innovative NPK products on sustainable maize production in NCP, however, the innovative fertilizers with effective additives should be properly selected for better economic benefits.

\section{Introduction}

Sustainable crop yield productivity and high nutrient use efficiency (NUE) is the key challenge in China (Liu et al., 2016; Guang-hao et al., 2021) since the current yield increase here relies heavily upon intensive resource use and generate serious environmental costs (Kumar, 2018; Ullah et al., 2015). For example, the average nitrogen ( $\mathrm{N}$ ) fertilizer in China is over $300 \mathrm{~kg} \mathrm{ha}^{-1}$ which is almost 4 times the world's $70 \mathrm{~kg} \mathrm{ha}^{-1}$ (Cui et al., 2018). Less than half of $\mathrm{N}$ fertilizer applied in China is taken up by crops with an average NUE of 25\% (Zhang et al., 2015) while the rest is largely lost in the environment (Alzaidi et al., 2013; Zhihui et al., 2016) eventually leading to low NUE, enhanced soil acidification (Guang-hao et al., 2020; Zant, 2010), and substantial reactive nitrogen (Nr) loss (Barman et al., 2017; Jagwe et al.,2020; Kalhapure et al., 2013; Nazli et al., 2014). Hence, an urgent question arises on how to address a more sustainable crop production (SCP) in China.

China is the second highest maize producer in the world accounting for more than one-third of Country cereal production (Niu et al., 2021) thus showing a large share for achieving SCP in China. However, currently, the farmer often produces maize in an unsustainable way due to overuse of N, phosphorus (P), and potassium (K), incorrect use of fertilizer products, inappropriate cultivation of plant density, and unsustainable management of soil and irrigation (Ji, Liu and Shi, 2020; van Wesenbeeck et al., 2021) Strategies maize towards SCP includes optimizing plant density, knowledge-based fertilizer practices, and use of efficiency fertilizer (Jiao et al., 2016). It has been widely recommended that the yield response to higher density is high if the maize yield potential is high since higher density rises the potential capacity of the crop canopy for capturing resources including water, nutrients, and solar radiations (De-yang et al., 2016; Sher et al., 2017; Du et al., 2021). Additionally, maize grain yield is determined by the final number of kernels per unit area at maturity which is the product of kernels numbers per ear and ear density (Yan et al., 2017). High NUE is achieved under higher planting density hence high biomass or $\mathrm{N}$ allocation and accumulation to grain (Xu et al., 2017). Knowledge-based fertilizer use approaches can be generalized by the 4R principle- the right rate, the right time, right product, and right placement for better balancing and synchronizing nutrient delivery and crop demands (T. Li et al., 2017; Adu-gyamfi et al., 2019; Jiang et al., 2019). Efficiency fertilizer includes; (i) urease inhibitor (UI) which delays the hydrolyzation rate of urea to ammonium $\left(\mathrm{NH}_{4}{ }^{+}\right)$to reduce ammonia $\left(\mathrm{NH}_{3}\right)$ emissions, (ii) nitrification inhibitor ( $\mathrm{NI}$ ) which blocks the microbial conversion of $\mathrm{NH}_{4}{ }^{+}$to $\mathrm{NO}_{3}{ }^{-}$to reduce the leaching (iii) polymer-coated material (PCF), and (iv) soil microbes inoculations (MI) to stimulates the rhizosphere nutrient cycling and root growth (Tian et al., 2016; G. Li et al., 2017; Jiang et al., 2018; Sikora et al., 2020). Although the effectiveness of single strategies mentioned above has often been examined, the integrated effects of combined strategies of optimizing plant density, balancing nutrient input, and innovating fertilizer products have few been studied. Understanding the integrated effects is urgently needed as there are many factors refers agronomy, technology, and fertilizer products that restrict the on-farming practice, therefore tend to demand integrated and comprehensive solutions.

Here, we have determined the effects of the combined strategy of optimizing plant density, balancing NPK input, and innovating one-time fertilizer products on maize yield, NUE, N surplus and economic benefit by a field experiment carried out in North China Plain (NCP). The present study aimed to evaluate whether the combined strategy (i) could obtain more yield attainable level, (ii) improve nutrient use efficiency, (iii) reduce $\mathrm{N}$ surplus, and (iv) increase net benefits.

\section{Materials And Methods}

\subsection{Description of the experimental site}

The field experiment was conducted at North China Plain, North-East of Hebei Province Luanna County $39^{\circ} 27^{\prime} 19^{\prime \prime}$ N Latitude, $118^{\circ} 36^{\prime} 15.3^{\prime \prime}$ E Longitude an elevation of 11 masl. Luanna County is categorized as a warm temperate semi-humid monsoon continental climate zone. The long-term (1990-2020) mean annual temperature of the area is $10.6^{\circ} \mathrm{C}$. The annual precipitation ranges from 400 to $800 \mathrm{~mm}$ intense heavily in summer. The field experiment was conducted in winter wheat-summer maize rotation systems of the 2020 season. Rotational cropping of winter wheat/summer maize with two harvests per year is the dominant cropping system. The farmers in the study area are mainly engaged in agricultural production and have good agricultural practices and experiences.

\subsection{Innovative fertilizer design}


In the present study, we designed a fertilizer product of ammonium sulfate urea (28-5-5) as a principle of green product innovation. To design a reasonable amount of $\mathrm{N}_{2} \mathrm{P}_{2} \mathrm{O}_{5}$, and $\mathrm{K}_{2} \mathrm{O}$ for maize we followed the principles of nutrient balance for the amount of nitrogen fertilizer and the available phosphorus and potassium nutrient in the soil for phosphorus and potassium fertilizer. Therefore the corresponding ratio (28-5-5) was the scientific ratio of $\mathrm{N}$, $\mathrm{P}_{2} \mathrm{O}_{5}$, and $\mathrm{K}_{2} \mathrm{O}$. Particularly, the average target yield of summer maize in North China is about 10 tons ha ${ }^{-1}$ which needs to absorb about $200 \mathrm{~kg}$ of pure nitrogen. According to China Agricultural University pres, 2009. 24. Zhang F S, Chen X P, Chen Q taking into account a large number of environmental nutrient inputs (about 60 kg $\mathrm{ha}^{-1}$ ) such as nitrogen deposition, non-symbiotically nitrogen fixation, and irrigation, the reasonable amount of $\mathrm{N}$ fertilizer was designed as $200 \mathrm{~kg}^{-1}$. Additionally, considering the amount of available phosphorus (about $60 \mathrm{mg} \mathrm{kg}^{-1}$ ) and available potassium (about $150 \mathrm{mg} \mathrm{kg}{ }^{-1}$ ) in most farmlands of North China is relatively high and most of the straw is returned to the field, the reasonable amount of $\mathrm{P}_{2} \mathrm{O}_{5}$, and $\mathrm{K}_{2} \mathrm{O}$ fertilizer is $35.6 \mathrm{~kg}$ ha ${ }^{-1}$.

The $\mathrm{N}$ sources in the present study were different. In farmer practice (FP) the $\mathrm{N}$ source was urea (46-0-0) which is water-soluble and has adverse effects on seed germination, early plant growth stages, and emits $\mathrm{CO} \otimes$ to the environment hence urea undergoes hydrolysis easily through urease enzyme after application to the soil, increasing soil pH and ammonia $\left(\mathrm{NH}_{3}\right)$ losses (Bremner and Krogmeier, 1988; Cantarella et al., 2018). In conventional fertilization (CF, $28-6-9,30-40 \%$ which is resign coating) the $\mathrm{N}$ source was mainly large particles coated urea which has high cost and unsatisfactory controlled release effects. Similarly, in the long term, the large-scale application will cause a large amount of non-degradable resin film to be harmed in the soil and pollute the soil indicating unsustainability (Lawrencia et al., 2021). In the innovative fertilizer, (IF, 28-5-5) product design ammonium sulfate and urea were mixed for synergy. Ammonium sulfate is a low-cost $\mathrm{N}$ fertilizer mixed with urea that has many beneficial effects. For instance, it can reduce ammonia volatilization, minimize nitrification rate, reduce leaching, and enhance fertilizer efficiency. Additionally, the sulfur elements in ammonium sulfate promote the absorption of $\mathrm{N}$ and activate the soil phosphorus and trace elements (de Graaff et al., 2019). In innovative fertilizer and urea inhibitors (IF+UI, 28-5-5) to increase the nitrogen use efficiency (NUE) urease inhibitors additive was added during the production of the fertilizer. Particularly urease inhibitors block the activity of the enzyme urease and protect against ammonia volatilization by keeping fertilizer $\mathrm{N}$ in the ammonium sulfate and urea form (Dong et al., 2016). In ammonium sulfate urea and double inhibitors (IF+DI, 28-5-5) urease inhibitors and nitrification inhibitors were used as synergies to reduce ammonium and nitrate loss (G. Li et al., 2017). Additionally, plant growth-promoting microorganisms of Bacillus subtilis bacteria was used as synergy in (IF+MI, 28-5-5). This Bacillus subtilis enhances plant growth mainly by the synthesis of plant hormones (auxin, cytokinin, and gibberellins) as well as the production of siderophores and antibiotics (Aquino et al., 2019; Holečková et al., 2017). Finally, ammonium sulfate urea with trace elements such as Copper (Cu), Iron (Fe), and Zinc (Zn) were used as synergy in (IF+TE, 28-5-5) as being building blocks for enzymes and facilitating a multitude of biochemical reactions (Sudhakaran et al., 2018; Vithanage et al., 2019).

\subsection{Experimental treatment details}

To estimate the maize yield potential in the Luanna County the Hybrid Maize model (Hybrid Maize, 2013) and 10 years local weather data were used indicating maize potential yield of about $15.6 \mathrm{Mg} \mathrm{ha}^{-1}$ at $14 \%$ moisture content and $14.6 \mathrm{Mg} \mathrm{ha}^{-1}$ grain dry matter when the density is about 78,000 plants population $\mathrm{ha}^{-1}$. The field experiment was laid out as a randomized complete block design (RCBD) with three replicates. The experiment had 8 treatments. Thus, there are $8 \times 3=24$ plots. The spacing between rows and plants was $50 \mathrm{~cm}, 25 \mathrm{~cm}$ respectively except for FP (farmer practice) which was planted at 60 $\mathrm{cm}, 25 \mathrm{~cm}$ since it was designed as 66,666 plants ha ${ }^{-1}$ while the other plant density was 78,000 plants ha $^{-1}$. The length of each plot was designed as $8 \mathrm{~m} \mathrm{x}$ $5 \mathrm{~m}$ and the area required for an experimental plot was $40 \mathrm{~m}^{2}$. The total area required for the experimental research was $960 \mathrm{~m}^{2}$ excluding the path between blocks and plots. Each plot had nine rows of which three to seven central rows were used for data collection and analysis and two rows of each plot side were left as border effect for the whole treatments except FP which had eight rows. The two outermost rows from each side and one plant from both ends of each row were considered as a border. The following was the table detail of treatments and nutrient inputs (Table 1).

Table 1

Detail of treatments and nutrient inputs.

\begin{tabular}{|c|c|c|c|c|c|c|c|c|c|c|c|}
\hline \multirow[t]{2}{*}{ Treatment } & \multirow[t]{2}{*}{ Plant density (plant ha ${ }^{-1}$ ) } & \multirow[t]{2}{*}{$\mathrm{N}$ forms (\%) } & \multicolumn{3}{|c|}{ Base fertilization $\left(\mathrm{Kg} \mathrm{ha}^{-1}\right)$} & \multicolumn{3}{|c|}{$\begin{array}{l}\text { Topdressing } \\
\left(\mathrm{Kg} \mathrm{ha}^{-1}\right)\end{array}$} & \multicolumn{3}{|c|}{ Total } \\
\hline & & & $\mathbf{N}$ & $\mathrm{P}_{2} \mathrm{O}_{5}$ & $\mathrm{~K}_{2} \mathrm{O}$ & $\mathbf{N}$ & $\mathrm{P}_{2} \mathrm{O}_{5}$ & $\mathrm{~K}_{2} \mathrm{O}$ & $\mathbf{N}$ & $\mathrm{P}_{2} \mathrm{O}_{5}$ & $\mathrm{~K}_{2} \mathrm{O}$ \\
\hline CK & 78,000 & - & - & - & - & - & - & - & - & - & - \\
\hline FP & 66,666 & 100 urea & 105 & 110 & 120 & 245 & - & - & 350 & 110 & 120 \\
\hline $\mathrm{CF}$ & 78,000 & 100 coated urea & 200 & 42.8 & 64.3 & - & - & - & 200 & 42.8 & 64.3 \\
\hline IF & 78,000 & 80 urea, $20\left(\mathrm{NH}_{4}\right)_{2} \mathrm{SO}_{4}$ & 200 & 35.6 & 35.6 & - & - & - & 200 & 35.6 & 35.6 \\
\hline $\mathrm{IF}+\mathrm{UI}$ & 78,000 & 80 urea, $20\left(\mathrm{NH}_{4}\right)_{2} \mathrm{SO}_{4}$ & 200 & 35.6 & 35.6 & - & - & - & 200 & 35.6 & 35.6 \\
\hline IF+DI & 78,000 & 80 urea, $20\left(\mathrm{NH}_{4}\right)_{2} \mathrm{SO}_{4}$ & 200 & 35.6 & 35.6 & - & - & - & 200 & 35.6 & 35.6 \\
\hline $\mathrm{IF}+\mathrm{MB}$ & 78,000 & 80 urea, $20\left(\mathrm{NH}_{4}\right)_{2} \mathrm{SO}_{4}$ & 200 & 35.6 & 35.6 & - & - & - & 200 & 35.6 & 35.6 \\
\hline IF+TE & 78,000 & 80 urea, $20\left(\mathrm{NH}_{4}\right)_{2} \mathrm{SO}_{4}$ & 200 & 35.6 & 35.6 & - & - & - & 200 & 35.6 & 35.6 \\
\hline
\end{tabular}

\subsection{Experimental Field management}

Deng-Hai (605) seed variety which adapts to the local area was used on June 22 to achieve the yield potential of the area. To make the soil smooth for RCBD layout and make easy emergence for seeds and grow the land was plowed once by tractor before sowing. To support soil quality and increase the soil carbon

Page 3/12 
content and yield of maize rotary into the soil was applied on the winter wheat straw. Field leveling was done by hand before sowing. Two seeds per hole were sown by dibbling at about $5 \mathrm{~cm}$ depth and the seeds were covered with soil manually to ensure adequate emergence. Thinning was done 10 days after emergence to one plant per hole to maintain the specified intra plant spacing. Base fertilization was applied at the base by hand having a 5-8 $\mathrm{cm}$ distance from the seeds to avoid the toxicity of fertilizer. For FP $30 \%$ of the $\mathrm{N}$ fertilizer was applied as base fertilizer while $70 \%$ was applied as top-dressing at thirty-five days after sowing. A little irrigation was used during the maize growing season and critical stages at emergence and silking to avoid water stress and achieve a high yield. To avoid a lodging growth inhibitor was applied once at V8 growth stages. One time herbicide was applied to control the weeds. Finally, the experiment was harvested on October 16 having 121 growing degree days to allow the late cobs filling and enough time for maturity.

\subsection{Soil Sampling and Analysis}

Soil samples were taken in a zigzag pattern before planting randomly from the experimental site at depth of 0-20 cm across the experimental field from 20 spots using an auger before planting and were composited. About $1.0 \mathrm{~kg}$ of soil composite sample was taken using a polythene bag to Quzhou soil laboratory test. Furthermore, after harvest $500 \mathrm{gm}$ composite samples from three randomly selected spots diagonally per plot were taken to test the soil nutrient content by using an auger at $0-20 \mathrm{~cm}$. The sample was dried at room temperature, systematically mixed, and crushed to pass through a $2 \mathrm{~mm}$ sieve in preparation for laboratory analysis. The sample was analyzed for soil texture, $\mathrm{pH}$, organic carbon, total nitrogen, available nitrogen, available phosphorus, and available potassium at the Quzhou laboratory test following standard analytical procedures.

\subsection{Maize and biomass yield measurement}

Yield and yield components measurement method

After the corn fills and matured (2020-10-17) the yield was measured by designing twenty (20) square meters in the middle of each plot as the production area. From the production area, the number of cobs per plant at harvest was counted. The total weights of cobs were measured and divided to get the mean cobs weights to select ten representative cobs for all yield and yield component evaluation and analysis.

\section{Aboveground dry biomass yield $\left(\mathrm{kg} \mathrm{ha}^{-1}\right)$}

It was recorded by taking the weight of 5 randomly selected representative plants at physiological maturity by using sensitive balance. The sample biomass was cut from the ground fresh plants into kraft paper bags, put in a constant temperature drying oven at $105^{\circ} \mathrm{C}$ for 30 minutes to deactivate enzymes, and then oven-dried at $80^{\circ} \mathrm{C}$ for 72 hours to determine dry matter yield. The average dry biomass per plant was multiplied by the number of total plants in the net plot area at harvest. It was expressed as dry biomass in $\mathrm{kg} \mathrm{ha}^{-1}$. Furthermore, this biomass yield was used for the calculation of the harvest index.

\section{The number of ears ha-1}

During harvesting, the number of ears from the production area was counted and scaled up to a hectare basis.

\section{Grain yield (ton ha ${ }^{-1}$ )}

It was recorded by threshing ten representative ears per plot by using field balance and converted to the total area per plot. The grain yield was cleaned and converted into ton $\mathrm{ha}^{-1}$, the yield was adjusted to a $14 \%$ moisture level, and finally, scaled up to a hectare basis.

\section{Hundred seed weight (gm)}

It was recorded by taking the weight of 100 randomly sampled seeds from the grain yield per plot by using a sensitive balance and the weight was adjusted to a $14 \%$ moisture level. The grain moisture content was measured by using a grain moisture meter while the kernel was counted by using a kernel counter.

\section{Harvest index (HI)}

It was computed as the ratio of grain yield $\left(\mathrm{kg} \mathrm{ha}^{-1}\right)$ to total above-ground dry biomass per ha.

\section{Nitrogen sustainability index analysis.}

\section{Partial factor productivity of nitrogen (PFPN)}

Partial factor productivity of nitrogen fertilizer was calculated as yield per unit inputs of nitrogen fertilizer for all treatments except for CK unfertilized control (treatment with no fertilization).

\section{Nitrogen uptake $\left(\mathrm{kg} \mathrm{ha}^{-1}\right)$}

The nitrogen uptake at harvest was calculated as the formula

Straw N uptake $=$ SNCT (the straw N concentration) X DMSW (the dry matter of straw weights).

Grain N uptake $=$ GNCT (the grains nitrogen concentration) X GW (the weight of the grains) .

Total $\mathrm{N}$ uptake $=$ straw $\mathrm{N}$ uptake + grain $\mathrm{N}$ uptake

\section{Nitrogen use efficiency}


The nitrogen use efficiency (NUE) was calculated by dividing the above-ground nitrogen uptake to applied nitrogen from fertilizer by using the following equation

$\mathrm{NUE}=\left(\mathrm{N}_{\text {uptake fertilized }}-\mathrm{N}_{\text {uptake unfertilized }}\right) / \mathrm{N}$ applied

Nitrogen surplus $\left(\mathrm{Kg} \mathrm{N} \mathrm{ha}^{-1} \mathrm{yr}^{-1}\right)$

The nitrogen surplus was calculated as the total of $\mathrm{N}$ inputs (fertilizer, irrigation, biologically fixed $\mathrm{N}$, and $\mathrm{N}$ deposition) minus $\mathrm{N}$ outputs (the $\mathrm{N}$ removed within harvested maize products, $\mathrm{N}_{\text {yield }}$ ).

\section{Cost benefits analysis}

To compute economic benefits analysis production cost composition includes land preparation and sowing, seed, fertilizer, topdressing, irrigation, thinning, and chemical controls for herbicides and pesticides were used. The labor cost during maize sowing and harvesting was 15 RMB hour ${ }^{-1}$. Harvest; output $=y i e l d$ $\mathrm{x}$ corn unit price $\left(2.5 \mathrm{RMB} \mathrm{kg}^{-1}\right)$. Lastly revenue (Net benefits) = output-production cots was followed to evaluate the net benefits.

\subsection{Statistical Data Analysis.}

All the measured parameters were subjected to analysis of variance (ANOVA) appropriate to factorial experiment in RCBD according to IBM SPSS statistics version 25. The mean record was equated using the Duncan Least Significant Differences (LSD) test at a $5 \%$ level of significance.

\section{Results}

\subsection{Soil physical and chemical properties of the study area.}

The initial soil physical and chemical properties (Table. 2) reveal that the texture classification was sandy loam, soil pH in water was 5.62 found in the medium acids (FAO, 2006), very low soil organic carbon (0.62\%), and moderate available P (39.8 ppm) (Landon, 2013).

Table 2

Physico-chemical characteristics of the soil before sowing.

\begin{tabular}{|lllllllllll|}
\hline Parameters and units & $\mathrm{pH}$ in $\mathrm{H}_{2} \mathrm{O}$ & $\%$ & \multicolumn{4}{c|}{ ppm } \\
\cline { 3 - 11 } & & & Sand & Clay & Silt & SOC & TN & Ava. N & Ava. P & Ava. K \\
\hline Value & 5.62 & 59.8 & 15.3 & 24.9 & 0.62 & 0.08 & 79.2 & 39.8 & 51.2 \\
\hline
\end{tabular}

The chemical properties of the soil after harvest (Table. 3) confirmed that IF \& IF+MI treatment was significantly higher than FP on soil pH. Except for the soil $\mathrm{pH}$ value, the result was insignificant on other soil chemical properties (SOM, OC, TN, Ava. N, Ava. P, and Ava. K) after harvest.

Table 3: The chemical characteristics of the soil after harvest.

\begin{tabular}{|c|c|c|c|c|c|c|c|}
\hline Treatments & $\mathrm{pH}\left(\mathrm{H}_{2} \mathrm{O}\right)$ & SOM (\%) & $\mathrm{OC}(\%)$ & TN (\%) & Ava. N (ppm) & $\begin{array}{l}\text { Ava. P } \\
\text { (ppm) }\end{array}$ & Ava. K (ppm) \\
\hline CK & $5.9 \pm 0.3^{a b}$ & $1.1 \pm 0.1^{\mathrm{a}}$ & $0.7 \pm 0.1^{a}$ & $0.07 \pm 0.01^{a}$ & $63.2 \pm 12.3^{a}$ & $25.9 \pm 9.5^{a}$ & $51.0 \pm .8 .2^{\mathrm{a}}$ \\
\hline FP & $5.6 \pm 0.2^{b}$ & $1.2 \pm 0.2^{\mathrm{a}}$ & $0.7 \pm 0.1^{a}$ & $0.07 \pm 0.01^{a}$ & $83.1 \pm 15.4^{\mathrm{a}}$ & $26.4 \pm 18.5^{a}$ & $57.0 \pm 4.0^{\mathrm{a}}$ \\
\hline CF & $5.8 \pm 0.2^{\mathrm{ab}}$ & $1.2 \pm 0.1^{\mathrm{a}}$ & $0.7 \pm 0.1^{\mathrm{a}}$ & $0.08 \pm 0.01^{a}$ & $72.5 \pm 3.2^{\mathrm{a}}$ & $32.1 \pm 8.3^{a}$ & $60.7 \pm 10.0^{a}$ \\
\hline IF & $6.2 \pm 0.4^{\mathrm{a}}$ & $1.4 \pm 0.1^{\mathrm{a}}$ & $0.8 \pm 0.1^{a}$ & $0.08 \pm 0.01^{a}$ & $71.1 \pm 0.6^{\mathrm{a}}$ & $25.3 \pm 9.4^{a}$ & $54.7 \pm 6.6^{\mathrm{a}}$ \\
\hline $\mathrm{IF}+\mathrm{UI}$ & $6.0 \pm 0.2^{\mathrm{ab}}$ & $1.1 \pm 0.3^{\mathrm{a}}$ & $0.7 \pm 0.1^{\mathrm{a}}$ & $0.08 \pm 0.01^{a}$ & $64.0 \pm 5.9^{a}$ & $29.2 \pm 2.1^{a}$ & $60.3 \pm 5.5^{a}$ \\
\hline IF+DI & $5.9 \pm 0.1^{a b}$ & $1.2 \pm 0.1^{\mathrm{a}}$ & $0.7 \pm 0.1^{\mathrm{a}}$ & $0.08 \pm 0.01^{a}$ & $67.2 \pm 12.3^{a}$ & $34.1 \pm 7.5^{a}$ & $54.7 \pm 5.0^{a}$ \\
\hline $\mathrm{IF}+\mathrm{MI}$ & $6.2 \pm 0.2^{\mathrm{a}}$ & $1.4 \pm 0.1^{\mathrm{a}}$ & $0.8 \pm 0.1^{a}$ & $0.09 \pm 0.01^{a}$ & $81.3 \pm 7.4^{\mathrm{a}}$ & $31.4 \pm 5.1^{a}$ & $56.0 \pm 4.0^{\mathrm{a}}$ \\
\hline $\mathrm{IF}+\mathrm{TE}$ & $5.9 \pm 0.1^{\mathrm{ab}}$ & $1.4 \pm 0.2^{\mathrm{a}}$ & $0.8 \pm 0.1^{a}$ & $0.09 \pm 0.01^{a}$ & $76.4 \pm 6.2^{\mathrm{a}}$ & $28.7 \pm 2.2^{\mathrm{a}}$ & $64.5 \pm 7.8^{a}$ \\
\hline
\end{tabular}

\subsection{Maize biomass, crop yields, and harvest index.}

\section{Above-ground dry biomass $\left(\mathrm{tha}^{-1}\right)$}

The CK had the lowest mean stalk, grain, and total dry matter while the highest was obtained from innovative fertilizers (Table. 4). In all types of dry matter, innovative fertilizer treatments (IF, IF+UI, IF+DI, IF+MI, \& IF+TE) were significant to CK. On average, the five innovative fertilizer total dry matter (IF, IF+UI, IF+DI, 
IF+MI, \& IF+TE) were $12 \%$ and $20.5 \%$ higher than FP and CK respectively. From innovative fertilizers, IF and IF+DI had achieved the highest (22.8) and lowest (22.0) total dry matter though the result was insignificant.

\section{Harvest index (\%)}

The mean harvest index ranges from $44.9-47.1 \%$ (Table. 4) however the result was insignificant.

Table 4

Mean values of above-ground dry biomass yield (ton ha-1) and harvest index (\%)

\begin{tabular}{|c|c|c|c|c|}
\hline Treatment & $\begin{array}{l}\text { Stalk dry matter } \\
\text { (ton } \mathrm{ha}^{-1} \text { ) }\end{array}$ & Grain dry matter (ton ha ${ }^{-1}$ ) & $\begin{array}{l}\text { Total dry matter } \\
\text { (ton } \mathrm{ha}^{-1} \text { ) }\end{array}$ & $\begin{array}{l}\text { Harvest index } \\
\text { (\%) }\end{array}$ \\
\hline CK & $9.7 \pm 0.8^{c}$ & $8.7 \pm 0.9^{c}$ & $18.4 \pm 0.8^{c}$ & $46.1 \pm 2.3^{a}$ \\
\hline FP & $11.0 \pm 1.2^{\mathrm{ab}}$ & $8.7 \pm 0.5^{c}$ & $19.8 \pm 0.5^{b c}$ & $45.0 \pm 1.7^{a}$ \\
\hline $\mathrm{CF}$ & $11.5 \pm 1.0^{\mathrm{ab}}$ & $9.5 \pm 0.3^{b}$ & $20.9 \pm 1.1^{\mathrm{ab}}$ & $46.7 \pm 2.4^{a}$ \\
\hline IF & $12.5 \pm 1.8^{a}$ & $10.3 \pm 0.7^{a}$ & $22.8 \pm 0.7^{a}$ & $46.4 \pm 4.0^{\mathrm{a}}$ \\
\hline $\mathrm{IF}+\mathrm{UI}$ & $11.7 \pm 1.7^{\mathrm{ab}}$ & $9.8 \pm 0.2^{a b}$ & $21.5 \pm 1.9^{\mathrm{ab}}$ & $46.2 \pm 3.4^{a}$ \\
\hline IF+DI & $12.2 \pm 2.1^{\mathrm{ab}}$ & $9.8 \pm 0.6^{\mathrm{ab}}$ & $22.0 \pm 1.6^{\mathrm{ab}}$ & $45.9 \pm 5.5^{\mathrm{a}}$ \\
\hline $\mathrm{IF}+\mathrm{MI}$ & $12.4 \pm 0.5^{a}$ & $9.7 \pm 0.1^{\mathrm{ab}}$ & $22.1 \pm 0.6^{\mathrm{ab}}$ & $44.9 \pm 0.3^{a}$ \\
\hline $\mathrm{IF}+\mathrm{TE}$ & $12.0 \pm 0.7^{\mathrm{ab}}$ & $10.4 \pm 0.1^{a}$ & $22.5 \pm 0.6^{a}$ & $47.1 \pm 2.2^{a}$ \\
\hline
\end{tabular}

The number of ears (No. ha $\left.{ }^{-1}\right)$ : The IF+UI and FP achieved the highest $(76,666.7)$ and lowest $(76,111.1)$ the number of ear ha ${ }^{-1}$ respectively $($ Table. 5$)$. Statistically, all innovation fertilizers (IF, IF+UI, IF+DI, IF+MI, \& IF+TE), CF, and CK were significant to FP. From innovative fertilizer, IF+UI and IF+DI achieved the highest $(76,666.7)$ and lowest $75,888.6$ number of ears ha ${ }^{-1}$ respectively however the result was insignificant.

The number of kernels ear ${ }^{-1}$ (No. plant ${ }^{-1}$ ): The IF+TE and CK ensured the highest (638.8) and lowest (539.1) number of kernels respectively (Table. 5). All fertilization (FP, CF, IF, IF+UI, IF+DI, IF+MI, and IF+TE) treatments were statistically significant to CK. From innovative fertilizer, IF+TE and IF+UI achieved the highest (638.8) and lowest (594.1) number of ears $\mathrm{ha}^{-1}$ respectively though the result was insignificant.

Hundred kernel weight (gm)

The FP achieved the highest (28.1) while CK had the lowest (26.2) hundred kernels weight respectively however not statistically significant (Table. 5).

\section{Grain yield (tonnes $\mathrm{ha}^{-1}$ )}

The highest (12.1) and lowest (10.1) grain yield was found from IF+TE and CK respectively (Table. 5). As a result, five innovative fertilizers (IF, IF+UI, IF+DI, $\mathrm{IF}+\mathrm{MI}$, and IF+TE) and CF were significant to FP and CK. On average the five innovative fertilizers (IF, IF+UI, IF+DI, IF+MI, and IF+TE) had achieved $14.9 \%$ and $13.8 \%$ yield better than CK and FP respectively. Additionally, IF+TE and IF were significantly higher than CF. From innovative fertilizer, IF+TE and IF+UI attained the highest (12.1) and lowest (11.3) grain yield respectively though the result was insignificant. 
Table 5

Mean number of ear ha-1, number of kernels ear-1, 100 kernel weights, grain yield

\begin{tabular}{|c|c|c|c|c|}
\hline Treatment & $\begin{array}{l}\text { Number of ears } \\
\mathrm{ha}^{-1}\end{array}$ & Number of kernel ear ${ }^{-1}$ & 100 kemel weights (gm) & $\begin{array}{l}\text { Grain yield } \\
\text { (ton ha-1) }\end{array}$ \\
\hline CK & $76,111 \cdot 1 \pm 962.3^{a}$ & $539.1 \pm 51.3^{c}$ & $26.2 \pm 1.5^{\mathrm{a}}$ & $10.1 \pm 0.1^{c}$ \\
\hline FP & $63,888.9 \pm 962.3^{b}$ & $622.8 \pm 70.0^{\mathrm{ab}}$ & $28.1 \pm 0.5^{a}$ & $10.2 \pm 0.6^{c}$ \\
\hline CF & $75,444.4 \pm 1424.5^{a}$ & $596.2 \pm 87.3^{\mathrm{ab}}$ & $26.3 \pm 1.4^{a}$ & $11.0 \pm 0.3^{b}$ \\
\hline IF & $76,111.1 \pm 1545.9^{a}$ & $632.6 \pm 68.1^{a}$ & $27.1 \pm 0.7^{a}$ & $12.0 \pm 0.3^{a}$ \\
\hline $\mathrm{IF}+\mathrm{UI}$ & $76,666.7 \pm 1166.7^{a}$ & $594.1 \pm 61.2^{\mathrm{ab}}$ & $27.0 \pm 0.9^{a}$ & $11.4 \pm 0.8^{\mathrm{ab}}$ \\
\hline $\mathrm{IF}+\mathrm{DI}$ & $75,888.6 \pm 1213.3^{a}$ & $599.4 \pm 57.1^{\mathrm{ab}}$ & $27.4 \pm 1.3^{a}$ & $11.4 \pm 0.7^{\mathrm{ab}}$ \\
\hline $\mathrm{IF}+\mathrm{MI}$ & $76,111.7 \pm 704.6^{a}$ & $602.2 \pm 64.9^{a b}$ & $27.1 \pm 1.2^{\mathrm{a}}$ & $11.3 \pm 0.2^{\mathrm{ab}}$ \\
\hline $\mathrm{IF}+\mathrm{TE}$ & $76,222 \cdot 2 \pm 907.1^{a}$ & $638.8 \pm 69.4^{a}$ & $27.2 \pm 1.1^{\mathrm{a}}$ & $12.1 \pm 0.1^{\mathrm{a}}$ \\
\hline
\end{tabular}

\subsection{Nitrogen sustainability index analyses}

\section{Nitrogen uptake}

In all nitrogen uptake forms, $\mathrm{CK}$ had always the lowest $\mathrm{N}$ uptake while the highest $\mathrm{N}$ uptake was found from innovative fertilizers irrespective of $\mathrm{N}$ forms (Fig. 1a). All innovative fertilizers (IF, IF+UI, IF+DI, IF+MI, \& IF+TE), CF, and FP had achieved statistically similar stalk $\mathrm{N}$ uptake ranging from 115.0 kg $\mathrm{N}$ ha ${ }^{-1}$ to $143.5 \mathrm{~kg} \mathrm{~N} \mathrm{ha}^{-1}$. All innovative treatments had higher grain $\mathrm{N}$ uptake than $\mathrm{CF}$, FP, and CK. From innovative fertilizer IF+TE and IF+MI had achieved the highest (302.6\%) and lowest (271.2\%) total N uptake however the result was insignificant. Furthermore, the total N uptakes in fertilization treatment were statistically similar but substantially significantly higher than the CK.

\section{Partial factor productivity of nitrogen (PFPN)}

The FP (29.0 kg yield/kg N) was half lower than the PFPN of other treatments (55.0-60.7 kg yield/kg N) (Fig. 1b). Statistically, five innovative fertilizers (IF, $\mathrm{IF}+\mathrm{UI}, \mathrm{IF}+\mathrm{DI}, \mathrm{IF}+\mathrm{MI}, \& \mathrm{IF}+\mathrm{TE})$ and $\mathrm{CF}$ were significantly higher than FP. From innovative fertilizer, IF+TE and IF+MI attained the highest (60.7 kg yield/kg N) and lowest (56.5 kg yield/kg N) PFPN respectively although the result was insignificant.

\section{Nitrogen use efficiency (NUE)}

The nitrogen use efficiency ranges from 19.0-51.1\% while the highest and lowest nitrogen use efficiency was found from IF+TE and FP respectively though statistically insignificant (Fg. 1b). From innovative fertilizer, IF+TE and IF+MI had achieved the highest (51.1\%) and lowest (35.4\%) NUE however the result was insignificant.

\section{Nitrogen surplus}

The FP achieved the significant and highest $\left(255.5 \mathrm{~kg} \mathrm{ha}^{-1}\right)$ more than two times higher than innovative fertilizers which range from $\left(73.9-88.7 \mathrm{~kg}^{-1}\right)$ (Fig. 1c). The result was insignificant among innovative fertilizers. On the other hand, CK had achieved the lowest and negative value of (-82.5 $\left.\mathrm{kg}^{-1}\right)^{-1}$.

3.4 Costs Benefits Analysis: The fertilizer cost of the innovation fertilizer (1,395-1,530 RMB ha-1) was significantly lower than FP (3,600 RMB ha $\left.{ }^{-1}\right)$ and CF $\left(2,175 \mathrm{RMB} \mathrm{ha}^{-1}\right)$ (Table. 6). The FP and CK had the highest and lowest cost respectively. The IF+TE and CK had the highest (30,250 RMB ha-1) and lowest $\left(25,250 \mathrm{RMB} \mathrm{ha}^{-1}\right)$ output respectively. The net benefits indicated that IF+TE and FP had achieved the highest $\left(21,250 \mathrm{RMB}^{-1}\right)$ and lowest $(14,250 \mathrm{RMB}$ $\mathrm{ha}^{-1}$ ) net benefit. The net income performance of the treatment in the sequence was: IF+TE, IF, IF+UI, IF+DI, IF+MI, CF, CK, and FP. 
Table 6

The cost and benefit analysis of different treatments (RMB ha -1)

\begin{tabular}{|c|c|c|c|c|c|c|c|c|c|c|c|c|c|}
\hline \multirow[t]{2}{*}{ Treatment } & \multicolumn{9}{|c|}{ Cost structure } & \multirow[t]{2}{*}{ Output } & \multirow{2}{*}{$\begin{array}{l}\text { Net } \\
\text { benefits }\end{array}$} & \multirow{2}{*}{$\begin{array}{l}\text { Increa. } \\
\text { (\%) CK }\end{array}$} & \multirow{2}{*}{$\begin{array}{l}\text { Rela.incr } \\
\text { (\%) FP }\end{array}$} \\
\hline & $\begin{array}{l}\text { Land } \\
\text { Pre \& } \\
\text { sowing }\end{array}$ & Seed & Fertilizer & Irrigation & Topdressing & Thinning & $\begin{array}{l}\text { Chem. } \\
\text { Cont. }\end{array}$ & Harvest & $\begin{array}{l}\text { Total } \\
\text { cost }\end{array}$ & & & & \\
\hline CK & 1800 & 825 & 0 & 1800 & 0 & 900 & 675 & 1500 & 7500 & 25250 & 17750 & - & - \\
\hline $\mathrm{FP}$ & 1800 & 825 & 3600 & 1800 & 150 & 900 & 675 & 1500 & 11250 & 25500 & 14250 & -19.7 & - \\
\hline CF & 1800 & 825 & 2175 & 1800 & 0 & 900 & 675 & 1500 & 9675 & 27500 & 17825 & 0.4 & 25.1 \\
\hline IF & 1800 & 825 & 1395 & 1800 & 0 & 900 & 675 & 1500 & 8895 & 30000 & 21105 & 18.9 & 48.1 \\
\hline $\mathrm{IF}+\mathrm{UI}$ & 1800 & 825 & 1470 & 1800 & 0 & 900 & 675 & 1500 & 8970 & 28500 & 18530 & 10.0 & 37.1 \\
\hline$|F+D|$ & 1800 & 825 & 1485 & 1800 & 0 & 900 & 675 & 1500 & 8985 & 28500 & 19515 & 9.9 & 36.9 \\
\hline IF+MI & 1800 & 825 & 1530 & 1800 & 0 & 900 & 675 & 1500 & 9030 & 28250 & 19220 & 8.3 & 34.9 \\
\hline $\mathrm{IF}+\mathrm{TE}$ & 1800 & 825 & 1500 & 1800 & 0 & 900 & 675 & 1500 & 9000 & 30250 & 21250 & 19.7 & 49.1 \\
\hline
\end{tabular}

CK, unfertilized control; FP, farmer practice; CF, conventional fertilization; IF, innovative fertilizer; IF+UI, innovative fertilizer and urea inhibitors additives; IF+DI, innovative fertilizer and double inhibitors additives; IF+MI, innovative fertilizer and micro-organisms additives, and innovative fertilizer and micro-organisms trace elements additives (IF+TE). Total Cost= Land Preparation and Sowing + Seed + Fertilizer + Irrigation + Top Dressing + Thinning + Chemical Control + Harvest; Output= Yield $\left(\mathrm{kg} \mathrm{ha}^{-1}\right)$ X $2.5 \mathrm{RMB}$; Net Benefits= Output-Total Cost.

\section{Discussion}

\subsection{Maize soil status.}

The acidity and low SOC on studied soil are mainly caused by high $\mathrm{N}$ inputs (over $300 \mathrm{~kg} \mathrm{ha}^{-1}$ ) and unsustainable soil management (i.e, intensive tillage, low inputs of organic fertilizer) which are mostly found in the North China Plain (Zhao et al., 2006; Huang et al., 2021). Additionally, the texture class of the present maize soil is sandy loam which tends to result in a low buffering capacity and a high rate of water percolation and infiltration thereby high risks of $\mathrm{N}$ leaching (Table. 2). In the present study, we designed the innovative fertilizer with multiple $\mathrm{N}$ forms $\left(\mathrm{NH}_{4}{ }^{+}-\mathrm{N}, \mathrm{Urea}-\mathrm{N}\right)$ and efficiency additives (UI, $\mathrm{DI}, \mathrm{MI}$, and TE) combined with the reasonable $\mathrm{N}, \mathrm{P}_{2} \mathrm{O}_{5}$, and $\mathrm{K}_{2} \mathrm{O}$ fertilizer and optimum plant density to explore the potential benefits on the soil. According to our result, the innovative fertilizer of IF and IF+MI soil pH (6.2) after harvest was significantly higher than FP (5.6) probably because of excess $\mathrm{N}, \mathrm{P}_{2} \mathrm{O}_{5}$, and $\mathrm{K}_{2} \mathrm{O}$ inputs in the case of FP. It suggests that an appropriate input of nutrients is beneficial for improvement on acidic soil. However, other soil chemicals' properties (SOM, OC, TN, Ava. N, Ava. P, and Ava. K) were insignificant probably due to the experiment being conducted for one season (Table. 3). Therefore, it needs further research to explore the long-term effects of innovative fertilizer on soil properties.

\subsection{Effect of innovative fertilizer on yield and yield potential}

The target of production is to gain a substantial and sustainable yield in unit mass which has been highlighted by numerous authors (Dong et al., 2016; Li et al., 2017). In this study, the five innovative fertilizers (IF, IF+UI, IF+DI, IF+MI, and IF+TE) and CF with $30 \%$ lower $\mathrm{N}$ input had achieved $13.1 \%$ higher yield than FP (Table. 5) which was mainly attributed to a higher plant density of 78,000 plants ha $^{-1}$ in five innovative fertilizers and $\mathrm{CF}$ than 66,666 plants ha $^{-1} \mathrm{FP}$ (Table. 1). Further results of yield components had shown that the increased grain yield per unit area is because of improved optimum plant population (number of ear $\mathrm{ha}^{-1}$ ) rather than increased grain yield per plant, with the same number of kernels ear ${ }^{-1}$, and 100 kernels weight.

Despite the largest $\mathrm{N}$ inputs from FP $\left(350 \mathrm{~kg} \mathrm{ha}^{-1}\right)$, there was a statistically similar yield between FP and CK. Overuse of $\mathrm{N}$ fertilizer has adverse effects on crops by minimizing $\mathrm{N}$ use efficiency (NUE) and increasing nitrate leaching losses as well as contamination of groundwater (Ngosong et al., 2019; Su et al., 2020). Furthermore, long-term application of ammonia-based $N$ fertilization like urea increases soil acidity which adversely affects soil fertility where crops fail to respond with more application of N fertilizers (M. Sainju, Ghimire and P. Pradhan, 2020). To know optimum N inputs levels, it is essential to know the level to which $\mathrm{N}$ fertilization rate is reliable with crop $\mathrm{N}$ needs to exploit resource utilization and sustain relatively high grain yields. In the present study, the highest grain yield was achieved under the innovative fertilizer of IF+TE (Table. 5) with reasonable N inputs of $200 \mathrm{~kg} \mathrm{ha}^{-1}$ (Table. 1). For the five innovative fertilizers with effective additives, the result was insignificant probably because the soil and climate conditions where the effective additives used may highly affect the final effects. For instance, urease inhibitors (IU) have little effect in acidic soils while the present study soil was medium acidic. Microorganisms (MI) additives have better performance on high SOC (T. Li et al., 2017; Sha et al., 2020) whereas our current study soil was low in SOC. Therefore, the effective additives should be targeted use according to the field biophysical settings.

The Hybrid Maize model estimates the yield potential of Luannan County as $15.6 \mathrm{Mg} \mathrm{ha}^{-1}$ at $14 \%$ moisture content and $14.6 \mathrm{Mg}^{-1} \mathrm{grain} \mathrm{dry}$ matter when the density is about 78,000 maize plants population $\mathrm{ha}^{-1}$. The five innovative fertilizers (IF, IF+UI, IF+DI, IF+MI, and IF+TE) achieved about 76.9\%, 73.1\%, 73.1\%, $72.4 \%$, and $77.6 \%$ of yield potential while CF, FP, and CK attained $70.5 \%, 65.4 \%$, and $64.7 \%$ respectively. On average, the five innovative fertilizers (IF, IF+UI, IF+DI, IF+MI, and IF+TE) achieved $74.6 \%$ yield potential while the research target was $85 \%$ yield potential of about $13.3 \mathrm{Mg}^{-1}$. In the present finding, the experiment had not achieved the research target probably because the experiment study soil was medium acidic soil. In the medium acidic soil pH category nutrients such as phosphorus, potassium, calcium, and molybdenum are adversely affected leading to a reduction in crop yields (FAO, 2006). 


\subsection{Effect of innovative fertilizer on nutrient use efficiency}

PFPN is an important indicator reflecting the efficiency of $\mathrm{N}$ fertilizer utilization. In this result, five innovative fertilizers (IF, IF+UI, IF+DI, IF+MI, and IF+TE) and CF PFPN were significantly higher than FP probably due to a reasonable amount of $\mathrm{N}$ inputs, optimum plant density, and high yield achieved (Fig. $1 \mathrm{~b}$ ). The five innovative fertilizers (IF, IF+UI, IF+DI, IF+MI, and IF+TE) had realized $100.5 \%$ and $5.9 \%$ higher than $\mathrm{FP}$ and $\mathrm{CF}$ respectively while IF+TE performed the highest PFPN. In this result, the high PFPN indicates that more output was produced from fertilizer application of $200 \mathrm{~kg} \mathrm{ha}^{-1} \mathrm{~N}$ for innovative fertilizers than $350 \mathrm{~kg}$ $\mathrm{ha}^{-1}$ for FP (Jia et al., 2013; Chen and Vyn, 2017). Similar results were reported by (Draman and Almas, 2009; Amanullah, 2016; Yan et al., 2016) in which optimum plant density and $\mathrm{N}$ inputs lead to better PFPN.

Within farming systems, many indicators ( $\mathrm{N}$ input, NUE indices, Soil mineral N, and N surplus) have been used to estimate potential $\mathrm{N}$ losses to the environment. Among these $\mathrm{N}$ surplus is an easily calculated indicator of the balance of $\mathrm{N}$ input minus $\mathrm{N}$ output. It has been used as a guideline for improving and promoting sustainable nutrient management within specified boundaries (Fernández et al., 2013; Børsting et al., 2003; Liang et al., 2019; Klages et al., 2020; Muratoglu, 2020). (Zhang et al., 2019) identified with the $\mathrm{N}$ surplus benchmark of $40-100 \mathrm{~kg} \mathrm{ha}^{-1} \mathrm{yr}^{-1} \mathrm{~N}$ and $110-190 \mathrm{~kg}^{-1} \mathrm{yr}^{-1} \mathrm{~N}$ for single and double-cropping systems in China respectively. In the present study, on average the five innovative fertilizers (IF, IF+UI, IF+DI, IF+MI, \& IF+TE) had achieved 81.7 $\mathrm{kg} \mathrm{ha}^{-1} \mathrm{yr}^{-1} \mathrm{~N}$ for single cropping which is within the recommended range and sustainable for $\mathrm{N}$ management (Fig. 1c). Additionally (Zhang et al., 2019) suggested minimum productivity level ( $\mathrm{N}$ harvest $=80 \mathrm{~kg} \mathrm{~N} \mathrm{ha}^{-1} \mathrm{yr}^{-1}$ ) which is almost similar to the present study. On the other hand, CK and FP had shown $-82.5 \mathrm{~kg} \mathrm{ha}^{-1} \mathrm{yr}^{-1} \mathrm{~N}$ and $255.5 \mathrm{~kg} \mathrm{ha}^{-1} \mathrm{yr}^{-1} \mathrm{~N}$ respectively for single cropping systems. Both largely positive and negative $\mathrm{N}$ surplus is unsustainable as the former often causes soil depletion, especially in long-term fertilization while the latter often causes high environmental risks of $\mathrm{N}$ losses.

Improving NUE is one of the most effective methods of increasing crop productivity while decreasing environmental degradation (Oenema, 2015; Venterea, Coulter and Dolan, 2016). In the present study on average, the five innovative fertilizers (IF, IF+UI, IF+DI, IF+MI, \& IF+TE) had achieved 41.2\% NUE (Fig. 1b). The average change of five innovative fertilizers in comparison to FP and CF was $117 \%$ and $42.6 \%$ respectively indicating high improvement of nutrient use efficiency in comparison to the current farmer practice. The NUE five innovative fertilizers in descending order were IF+TE, IF+DI, IF, IF+UI, and IF+MI respectively. However, the average NUE of five innovative fertilizers (41.2\%) is still below the suggested range for NUE (50\%-90\%) according to the EU Nitrogen Expert Panel (Zhang et al., 2019) which needs further improvement.

\subsection{Effect of innovative fertilizer on economic analysis}

From an economic perspective, the essential parameters during the assessment of agricultural systems are achieved yield and its technological parameters (Niemiec and Komorowska, 2018). Farmers consider the economic benefits and risks based on the fertilizer and grain prices when newly designed fertilizer is used (LI et al., 2021). In the present study, in compared to FP and CF, on average, the five innovative fertilizers (IF, IF+UI, IF+DI, IF+MI, and IF+TE) reduced the cost of production by $25.0 \%$ and $7.9 \%$ and additionally generated $11.6 \%$ and $4.8 \%$ higher output, thereby achieved $29.2 \%$ and $11.4 \%$ net benefits (Table. 6 ). It suggests that the innovative fertilizer has more economic advantage than FP and CF because of the advantage in increased grain yield, decreased cost of fertilizer, and decreased labor costs with a one-time application. In comparison to IF only, the four innovative fertilizers with effective additives (UI, DI, MI, and TE) had averagely increased $7.3 \%$ higher cost of production, while generating $3.9 \%$ lower output and resulting in $6.2 \%$ lower net benefits. It suggests that most innovative fertilizers with effective additives just increased the cost of production rather than obtain more benefits on output due to the limited improvement in yield.

\section{Conclusion}

Sustainable maize production requires a high yield with less inputs as well as minor environmental impacts. Our result had demonstrated that the combined strategy of optimizing plant density, balancing NPK inputs, and innovating NPK fertilizer products is critical for sustainable maize production in NCP with more comprehensive benefits on yield, NUE, N surplus, and economic gains compared to the most common farmer practice. Meaningfully, this combined strategy is an agronomically robust and relatively easy way to adopt but much relies on innovations operations with knowledge researchers, extension governments, and fertilizer-product markets. Moreover, this combined strategy should be variable across different regionals soil and climate which may require differential plant density, nutrient inputs, and fertilizer characteristics as well as effective additives. Therefore, it highlights a regional environment-oriented design on the combined strategy to meet multiple objectives such as achieving high-cost saving, efficiency increasing as well as sustainable and green development.

\section{Declarations}

\section{Maize collection guidelines statement: This is to confirm that all local, national or international guidelines and legislation were adhered to in the production of this study.}

Data availability: The data that support the findings of this study are available from Tesema Feyissa but restrictions apply to the availability of these data, which were used under license for the current study, and so are not publicly available. Data are however available from the authors upon reasonable request and with permission of Tesema Feyissa (email: tesemafayyisaa@gmail.com). \{Only to be included in the email for non-research articles e.g. study protocols or literature reviews\}.

Acknowledgment: The authors of the paper express their sincere gratitude to all partners involved in the development of this research. First, we would like to acknowledge the National Key Technologies R\&D Program of China for financial support. Second, the authors owe sincere gratitude to Fengtianbao Agricultural Science and Development and Technology Co. LTD for the innovative fertilizer product preparation. Additionally, Special thanks also go to the School of Resource and Environmental Science of China Agricultural University, and Quzhuo Soil laboratory expertise and technicians.

Page $9 / 12$ 
Author contributions:

Conceptualizations: Shuaixiang Zhao, Weifeng Zhang, Tesema Feyissa, Ma Hailong, Duan Zhiping.

Data curation: Tesema Feyissa, Ma Hailong, Duan Zhiping.

Funding acquisition and project administration: Shuaixiang Zhao, Weifeng Zhang

Writing an original draft paper: Tesema Feyissa

Writing-review \& editing: Shuaixiang Zhao, Tesema Feyissa

Supervision: Weifeng Zhang. All authors have read and agreed to the published version of the manuscript.

Conflict of interest: Regarding this paper, the author declares no conflict of interest.

\section{References}

1. Amanullah (2016) 'Rate and timing of nitrogen application influence partial factor productivity and agronomic NUE of maize (Zea mays $L$ ) planted at low and high densities on calcareous soil in northwest Pakistan', Journal of Plant Nutrition, 39(5), pp. 683-690. DOI: 10.1080/01904167.2015.1087031.

2. de Aquino, J. P. A. et al. (2019) 'Plant growth-promoting endophytic bacteria on maize and sorghum1', Pesquisa Agropecuaria Tropical, 49, pp. 1-9. DOI: 10.1590/1983-40632019v4956241.

3. Børsting, C. F. et al. (2003) 'Reducing nitrogen surplus from dairy farms. Effects of feeding and management, Livestock Production Science, 83(2-3), pp. 165-178. DOI: 10.1016/S0301-6226(03)00099-X.

4. Bremner, J. M. and Krogmeier, M. J. (1988) 'Elimination of the adverse effects of urea fertilizer on seed germination, seedling growth, and early plant growth in soil', Proceedings of the National Academy of Sciences, 85(13), pp. 4601-4604. DOI: 10.1073/pnas.85.13.4601.

5. Carmen Fernándeza, G. K. \& M. F. J. S. (2013) 'Journal of the American Statistical Association Multiple-Output Production With Undesirable Outputs Multiple-Output Production With Undesirable Outputs: An Application to Nitrogen Surplus in Agriculture', Journal of the American Statistical Association, 97(458), pp. 432-442.

6. Chen, K. and Vyn, T. J. (2017) 'Post-silking Factor Consequences for N Efficiency Changes Over 38 Years of Commercial Maize Hybrids', Frontiers in Plant Science, 8(October). DOI: 10.3389/fpls.2017.01737.

7. Cui, Z. et al. (2018) 'Pursuing sustainable productivity with millions of smallholder farmers', Nature. Nature Publishing Group, 555(7696), pp. $363-366$. DOI: $10.1038 /$ nature25785.

8. De-yang, S. H. I. et al. (2016) 'Increased plant density and reduced N rate lead to more grain yield and higher resource utilization in summer maize', Journal of Integrative Agriculture. Chinese Academy of Agricultural Sciences, 15(11), pp. 2515-2528. DOI: 10.1016/S2095-3119(16)61355-2.

9. Dong, Y. J. et al. (2016) 'Effects of new coated release fertilizer on the growth of maize', Journal of Soil Science and Plant Nutrition, 16(3), pp. 637-649. DOI: $10.4067 /$ s0718-95162016005000046.

10. Draman, A. and Almas, L. K. (2009) 'Partial Factor Productivity, Agronomic Efficiency, and Economic Analyses of Maize in Wheat-Maize Cropping System in Pakistan', Southern Agricultural Economics Association Annual Meetings, (January 2009).

11. Du, X. et al. (2021) 'Increased planting density combined with reduced nitrogen rate to achieve high yield in maize', Scientific Reports. Nature Publishing Group UK, 11(1), pp. 1-12. DOI: 10.1038/s41598-020-79633-z.

12. FAO (2006) Guidelines for soil description, Enhanced Recovery After Surgery. DOI: 10.1007/978-3-030-33443-7_3.

13. de Graaff, M. A. et al. (2019) 'Effects of agricultural intensification on soil biodiversity and implications for ecosystem functioning: A meta-analysis', Advances in Agronomy, 155, pp. 1-44. DOI: 10.1016/bs.agron.2019.01.001.

14. Guang-hao, L. I. et al. (2020) 'Differences of yield and nitrogen use efficiency under different applications of slow-release fertilizer in spring maize', Integrative Agriculture, 19(0), pp. 2-12. DOI: 10.1016/S2095-3119(20)63315-9.

15. Guang-hao, L. I. et al. (2021) 'Differences of yield and nitrogen use efficiency under different applications of slow-release fertilizer in spring maize', Journal of Integrative Agriculture. CAAS. Publishing services by Elsevier B.V, 20(2), pp. 554-564. DOI: 10.1016/S2095-3119(20)63315-9.

16. Huang, S. et al. (2021) 'Estimation of nitrogen supply for summer maize production through a long-term field trial in china', Agronomy, 11(7). DOI: 10.3390/agronomy11071358.

17. Ji, Y., Liu, H. and Shi, Y. (2020) 'Will China's fertilizer use continue to decline? Evidence from LMDI analysis based on crops, regions and fertilizer types', PLoS ONE, 15(8 August). DOI: 10.1371/journal.pone.0237234.

18. Jia, X. ping et al. (2013) 'Farmer's Adoption of Improved Nitrogen Management Strategies in Maize Production in China: An Experimental Knowledge Training', Journal of Integrative Agriculture. Chinese Academy of Agricultural Sciences, 12(2), pp. 364-373. DOI: 10.1016/S2095-3119(13)60237-3.

19. Jiang, C. et al. (2018) 'One-time root-zone N fertilization increases maize yield, NUE and reduces soil N losses in lime concretion black soil', Scientific Reports. Springer US, 8(1), pp. 1-10. DOI: 10.1038/s41598-018-28642-0.

20. Jiao, X. et al. (2016) 'Grain production versus resource and environmental costs: towards increasing sustainability of nutrient use in China', 67(17), pp. 4935-4949. DOI: 10.1093/jxb/erw282.

21. Klages, S. et al. (2020) 'Nitrogen surplus-a unified indicator for water pollution in Europe?', Water (Switzerland), 12(4). DOI: 10.3390/W12041197. 
22. Landon, J. (2013) Booker Tropical Soil Manual: A Handbook for Soil Survey and Agriculture Land Evaluation in the Tropics and Subtropics.

23. Lawrencia, D. et al. (2021) 'Controlled-release fertilizers: A review on coating materials and mechanism of release', Plants, 10(2), pp. 1-26. DOI: $10.3390 /$ plants 10020238 .

24. Li, G. et al. (2017) 'Impact of controlled-release urea on maize yield and nitrogen use efficiency under different water conditions', PLoS ONE, 12(7), pp. 116. DOI: $10.1371 /$ journal.pone.0181774.

25. LI, G. hao et al. (2021) 'Differences of yield and nitrogen use efficiency under different applications of slow-release fertilizer in spring maize', Journal of Integrative Agriculture. CAAS. Publishing services by Elsevier B.V, 20(2), pp. 554-564. DOI: 10.1016/S2095-3119(20)63315-9.

26. Li, T. et al. (2017) Enhanced-efficiency fertilizers are not a panacea for resolving the nitrogen problem. D0I: 10.1111/ijlh.12426.

27. Liang, K. et al. (2019) 'Reducing nitrogen surplus and environmental losses by optimized nitrogen and water management in double rice cropping system of South China', Agriculture, Ecosystems, and Environment. Elsevier, 286(September 2019), p. 106680. D0I: 10.1016/j.agee.2019.106680.

28. Liu, H. et al. (2016) 'Agriculture, Ecosystems, and Environment Optimal nitrogen input for higher efficiency and lower environmental impacts of winter wheat production in China', 'Agriculture, Ecosystems, and Environment. Elsevier B.V., 224, pp. 1-11. DOI: 10.1016/j.agee.2016.03.022.

29. M. Sainju, U., Ghimire, R. and P. Pradhan, G. (2020) 'Nitrogen Fertilization I: Impact on Crop, Soil, and Environment', Nitrogen Fixation, (3), pp. 1-24. DOI: 10.5772/intechopen.86028.

30. Muratoglu, A. (2020) 'Grey water footprint of agricultural production: An assessment based on nitrogen surplus and high-resolution leaching runoff fractions in Turkey', Science of the Total Environment. Elsevier B.V., 742, p. 140553. DOI: 10.1016/j.scitotenv.2020.140553.

31. Nazli, R. I. et al. (2014) 'Effects of different organic materials on forage yield and quality of silage maize (Zea mays L.)', Turkish Journal of Agriculture and Forestry, 38(1), pp. 23-31. DOI: 10.3906/tar-1302-62.

32. Ngosong, C. et al. (2019) ' Optimizing Nitrogen Fertilization Regimes for Sustainable Maize (Zea mays L.) Production on the Volcanic Soils of Buea Cameroon ', Advances in Agriculture, 2019, pp. 1-8. DOI: 10.1155/2019/4681825.

33. Niemiec, M. and Komorowska, M. (2018) 'The Use of Slow-Release Fertilizers as a Part of Optimization of Celeriac Production Technology', Agricultural Engineering, 22(2), pp. 59-68. DOI: 10.1515/agriceng-2018-0016.

34. Niu, Z. et al. (2021) 'Total factor productivity growth in china's corn farming: An application of generalized productivity indicator', Journal of Business Economics and Management, 22(5), pp. 1189-1208. DOI: 10.3846/jbem.2021.15105.

35. Oenema, O. (2015) 'Nitrogen use efficiency (NUE) an indicator for the utilization of nitrogen in food systems', EU Nitrogen Expert Panel, (January 2017), pp. 1-4.

36. Sha, Z. et al. (2020) 'Effect of N stabilizers on fertilizer-N fate in the soil-crop system: A meta-analysis', Agriculture, Ecosystems and Environment, 290(September 2019). DOI: 10.1016/j.agee.2019.106763.

37. Sher, A. et al. (2017) 'Response of Maize Grown Under High Plant Density; Performance, Issues, and Management - A Critical Review', Advances in Crop Science and Technology, 05(03). DOI: 10.4172/2329-8863.1000275.

38. Sikora, J. et al. (2020) 'Assessment of the efficiency of nitrogen slow-release fertilizers in integrated production of carrot depending on fertilization strategy', Sustainability (Switzerland), 12(5), pp. 1-10. DOI: 10.3390/su12051982

39. Su, W. et al. (2020) 'Nitrogen fertilization affects maize grain yield through regulating nitrogen uptake, radiation and water use efficiency, photosynthesis and root distribution', PeerJ, 8, pp. 1-21. DOI: 10.7717/peerj.10291.

40. Sudhakaran, M. et al. (2018) 'Assessment of trace elements and its influence on physicochemical and biological properties in coastal agroecosystem soil, Puducherry region', Geology, Ecology, and Landscapes. Taylor \& Francis, 9508, pp. 1-8. DOI: 10.1080/24749508.2018.1452475.

41. Tian, C. et al. (2016) 'Effects of a controlled-release fertilizer on yield, nutrient uptake, and fertilizer usage efficiency in early ripening rapeseed (Brassica napus L.) *', Journal of Zhejian University-Science B (Biomedicine \& Biotechnology), 17(14), pp. 775-786.

42. Venterea, R. T., Coulter, J. A. and Dolan, M. S. (2016) 'Evaluation of Intensive "4R" Strategies for Decreasing Nitrous Oxide Emissions and Nitrogen Surplus in Rainfed Corn', Journal of Environmental Quality, 45(4), pp. 1186-1195. DOI: 10.2134/jeq2016.01.0024.

43. Vithanage, M. et al. (2019) 'Occurrence and cycling of trace elements in ultramafic soils and their impacts on human health: A critical review', Environment International. Elsevier, 131(June), p. 104974. DOI: 10.1016/j.envint.2019.104974.

44. van Wesenbeeck, C. F. A. et al. (2021) 'Can China's overuse of fertilizer be reduced without threatening food security and farm incomes?', Agricultural Systems. Elsevier Ltd, 190(February), p. 103093. DOI: 10.1016/j.agsy.2021.103093.

45. Xu, C. et al. (2017) 'Manipulating planting density and nitrogen fertilizer application to improve yield and reduce environmental impact in Chinese Maize production', Frontiers in Plant Science, 8(July), pp. 1-11. DOI: 10.3389/fpls.2017.01234.

46. Yan, P. et al. (2016) 'Interaction between plant density and nitrogen management strategy in improving maize grain yield and nitrogen use efficiency on the North China Plain', Agricultural Sciences, 154, pp. 978-988. DOI: 10.1017/S0021859615000854.

47. Yan, P. et al. (2017) 'A high plant density reduces the ability of maize to use soil nitrogen', PLoS ONE, 12(2), pp. 1-12. DOI: 10.1371/journal.pone.0172717.

48. Zhang, C. et al. (2019) 'Nitrogen Surplus Benchmarks for Controlling N Pollution in the Main Cropping Systems of China', Environmental Science and Technology, 53(12), pp. 6678-6687. DOI: 10.1021/acs.est.8b06383.

49. Zhang, X. et al. (2015) 'Managing nitrogen for sustainable development, Nature. Nature Publishing Group, 528(7580), pp. 51-59. DOI: 10.1038/nature15743.

50. Zhao, R. F. et al. (2006) 'Fertilization and nitrogen balance in a wheat-maize rotation system in North China', Agronomy Journal, 98(4), pp. 938-945. D0I: 10.2134/agronj2005.0157. 
51. Zhihui, W. E. N. et al. (2016) 'Combined Applications of Nitrogen and Phosphorus Fertilizers with Manure Increase Maize Yield and Nutrient Uptake via Stimulating Root Growth in a Long-Term Experiment', Pedosphere: An International Journal. Soil Science Society of China, 26(1), pp. 62-73. DOI: 10.1016/S1002-0160(15)60023-6.

\section{Figures}
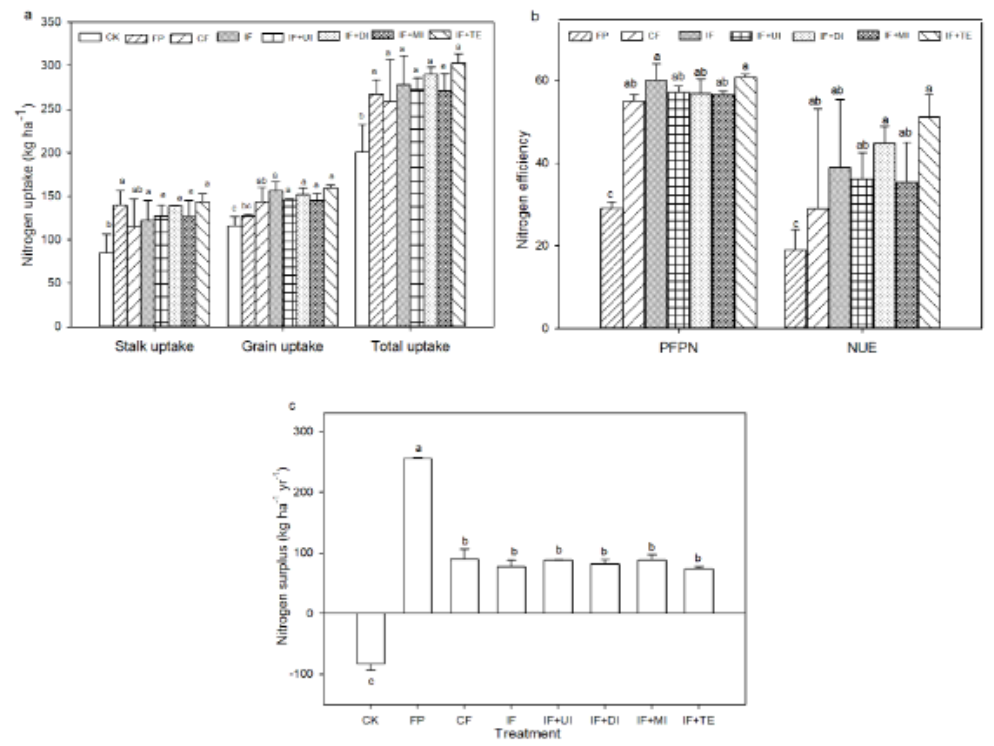

\section{Figure 1}

Nitrogen uptake (a), Partial factor productivity of nitrogen (PFPN) (b), Nitrogen use efficiency (NUE) (b), and Nitrogen surplus (total N input minus total N uptake) (c). CK, unfertilized control; FP, farmer practice; CF, conventional fertilization; IF, innovative fertilizer; IF+UI, innovative fertilizer and urea inhibitors additives; IF+DI, innovative fertilizer and double inhibitors additives; IF+MI, innovative fertilizer and micro-organisms additives, and innovative fertilizer and micro-organisms trace elements additives $(\mathrm{IF}+\mathrm{TE})$. All values are reported as mean $\pm S D, n=3$. The values followed by the different letters show statistically significant differences at $\mathrm{P} \otimes 0.05$. 